\title{
A potential new frost heave mechanism in high-speed railway embankments
}

\author{
D. SHENG ${ }^{*} \dagger$, S. ZHANG $\dagger$, F. NIU $\ddagger$ and G. CHENG $\ddagger$
}

\begin{abstract}
Substantial frost heave has been observed in coarse fills in high-speed railway embankments. These coarse fills have very low water contents, and are located above the groundwater table. In an attempt to explain the unexpected frost heave, it is proposed that cyclic train loads cause the development of excess pore water pressure in the underlying subgrade soil, and hence 'pump' up the water table to the frost front, which in turn feeds the formation of ice and results in continuous frost heave. A simple quantitative model is then developed to simulate the pumping-enhanced frost heave. The numerical results show that the proposed mechanism can indeed provide a rational explanation for the otherwise unexpected frost heave. The engineering implications of this new frost heave mechanism are also discussed, in the context of designing frost heave mitigation measures in seasonally frozen regions.
\end{abstract}

KEYWORDS: embankments; ground freezing; numerical modelling; pore pressures; snow ice and frost

\section{INTRODUCTION}

Substantial frost heave has been observed in railway embankments along the recently constructed high-speed railway between Harbin and Dalian in northern China - the socalled Ha-Da-Shian. The embankment construction was completed by June 2010, and the rail line has been operating since October 2012. The actual amounts of heave observed during the period between October 2012 and January 2013 are of the order of $5 \mathrm{~mm}$ on average and $20 \mathrm{~mm}$ at maximum. The observed frost heave has been a cause of great concern to the Chinese railway authorities, and is one of the main reasons why the train speed is now limited to $180 \mathrm{~km} / \mathrm{h}$ in winter seasons, a significant decrease from the original design speed of $350 \mathrm{~km} / \mathrm{h}$, or the operational speed of $300 \mathrm{~km} / \mathrm{h}$ in summer seasons.

Monitored displacements and temperatures indicate that frost heave is widespread along the $920 \mathrm{~km}$ railway, but has occurred mainly in coarse fills that were considered not susceptible to frost heave. These coarse fills, classified as Group A and Group B in the Chinese standard, have low fine contents (typically $\sim 10 \%$ ) and very low water content (typically $\sim 5 \%$ in mass). The groundwater table is located below the coarse fills. The maximum frost penetration depth monitored so far is within these coarse fills. Similar frost heave occurrences have also been reported for the QinhuangdaoShenyang passenger train rail line, the first high-speed railway in China (Li, 2008).

It is difficult to explain the observed heave using existing theories. Much of the media attention has accentuated the engineering quality of the construction, but this paper attempts to study the problem from a more scientific perspective: the interaction between cyclic train loads and frost

Manuscript received 18 March 2013; revised manuscript accepted 30 August 2013. Published online ahead of print 23 October 2013.

Discussion on this paper closes on 1 July 2014, for further details see p. ii.

* Centre of Excellence for Geotechnical Science and Engineering, The University of Newcastle, Callaghan, NSW, Australia.

$\uparrow$ National Engineering Laboratory for High-Speed Railway Construction, Central South University, Changsha, China.

+ State Key Laboratory of Frozen Soil Engineering, Cold and Arid Regions Environmental and Engineering Research Institute, Lanzhou, China. heave. The intention is to explore the possibility of a new frost heave mechanism that was not considered during the design and construction of the railway embankments, and which may challenge the common engineering practices for mitigating frost heave in cold regions.

Frost heave refers to the volume expansion when a soil freezes. It is one of the two most detrimental effects of frost action in seasonally frozen soils, the other being thawweakening. Longitudinal cracks observed in the centre of pavements during winter seasons are typical results of differential frost heave. High-speed trains are particularly sensitive to frost heave, as their safety and serviceability very much depend on strictly controlled track displacement. In China, the maximum allowed vertical displacement after completion of construction is $15 \mathrm{~mm}$. Because significant frost heave is usually due to the accumulation of ice lenses in the soil, it is in essence also responsible for or the cause of thaw-weakening. A frozen soil without much ice does not generate much excess pore pressure or lose much of its strength when it thaws in spring time. It is therefore crucial to understand and hence correctly predict frost heave in freezing soils.

Freezing of a moist soil is a process that couples heat and mass transfer. When a saturated fine-grained soil is subjected to a subfreezing temperature, part of the water in the soil pores first solidifies into ice - that is, pore ice particles. But close to the soil particles, and more tightly bound to them, a film of unfrozen water remains. This adsorbed water film has lower free energy at a lower negative temperature. Therefore a gradient in the water potential develops in the same direction as the temperature gradient. Water can then be sucked up from the warm portion to feed the accumulation of pore ice. As the pore ice particles grow, they can eventually connect to each other and form an ice lens, oriented perpendicular to the direction of heat and water flow. The availability of water mass from a reservoir (for example, the groundwater table) is another condition for significant frost heave. Freezing of a closed soil column can generate only a limited amount of heave, that is, $9 \%$ of the frozen pore water volume. In such a closed system, the heave in the frozen soil is offset by the consolidation in the unfrozen soil. Only in an open system, where external water can flow in to feed the ice lens formation and growth, does 
significant frost heave then take place. In fact, frost heave observed in the field or the laboratory is usually due to ice lens formation associated with water migration in finegrained soils.

On the other hand, coarse-grained soils have long been recognised as not being susceptible to frost heave (Beskow, 1935). In coarse-grained soils that are located above the groundwater table, the water content and especially the unfrozen water content in a frozen soil are very low, so that the liquid water phase is usually discontinuous. When the frost penetration depth is far above the groundwater table, it is difficult for water to flow to the frost front or the frozen fringe. Indeed, the frozen fringe (the zone between the frost front and the warmest ice lens; Miller, 1972) in a coarse soil such as sand is very thin, or zero. Therefore freezing of coarse soils such as sand and gravel does not usually cause the formation of thick ice lenses, or much frost heave. An exceptional case occurs when the frost front reaches the groundwater table. In this case, the groundwater will provide the source of mass for ice formation and growth. The selfpurification nature of ice will lead to a very thick ice lens just behind the frost front (Cheng, 1983). The eventual frost heave is limited only by the availability of groundwater and the length of the freezing period.

Another well-known phenomenon in railway geotechnics is so-called mud pumping, which refers to the upward flow of fine content and water from saturated subgrade soils towards the ballast under train cyclic loads, degrading the ballast quality (Machii, 1978; Selig \& Water, 1994; Alobaidi \& Hoare, 1996). Mud pumping also occurs in ballastless high-speed railway embankments. For example, significant problems of mud pumping were reported along the Japanese Shikansen railway (Hayashi \& Shahu, 2000; Muramoto et al., 2006). It is also well known that cyclic loading on a saturated soil can lead to accumulated volume change under drained conditions, or excess pore pressure under undrained conditions. The latter case is the essential reason for sand and silt liquefaction during earthquakes. The cyclic train loads can also cause the development of excess pore pressure in the foundation soil under railway embankments, which may then drive the water up into the ballast layer. Mud pumping (flow of fine contents) does not always take place in railway embankments, whereas some excess pore pressure in the foundation soil is generally expected to occur, owing to train loads. The actual development of the excess pore pressure depends on various factors, such as the train load and speed, the depth of the soil, and its hydromechanical properties.

Although frost heave and mud pumping are both well known and well documented in the geotechnical literature, their interaction has not been considered. In this paper the authors investigate the interaction of these two phenomena, in an attempt to explain the observed frost heave under otherwise unexpected situations. As the specific problem that has motivated the study is not open for independent analysis, the paper only demonstrates a potential new frost heave mechanism in high-speed railway embankments, and the conclusions derived from this study are thus provisional. An important outcome of this paper is to stimulate further research into a very interesting problem.

The paper is organised as follows. It first proposes a simple framework that underlines the interaction between train-induced excess pore pressure and frost heave in railway embankments. A frost heave model is proposed to incorporate the effects of the excess pore water pressure on the coupled heat and mass transfer in freezing soils. Numerical examples are then presented, to justify the validity of the pumping-enhanced frost heave mechanism. The effectiveness of common frost heave mitigation measures is finally discussed, in conjunction with the proposed frost heave mechanism.

MECHANISM OF PUMPING-ENHANCED FROST HEAVE

Liu et al. $(2011,2012)$ presented a couple of Ha-Da-Shian railway embankment profiles and field measurements of frost depth and frost heave in the 2010-2011 winter, the first winter since the completion of the embankment. Fig. 1 shows such a typical embankment profile. The coarse fill is about $2.9 \mathrm{~m}$ thick, underlying a layer of sub-ballast of $0.6 \mathrm{~m}$ and overlying a thick layer of silty loess or clayey loess. The coarse fill in the embankment is classified as Group A and $\mathrm{B}$ fills, and has a fines content (grain size $<0.075 \mathrm{~mm}$ ) typically less than $15 \%$ and an in situ water content between $3 \%$ and $8 \%$ in mass. Typical particle size distributions of these fills are shown in Fig. 2(a). The general requirements for these fills are that the maximum grain diameter is $60 \mathrm{~mm}$ and the fine content is less than $15 \%$. The main difference between Group A and Group B fills is that the former are well graded, with $C_{\mathrm{u}}=D_{60} / D_{10}>5$ and $1<C_{\mathrm{c}}=\left(D_{30}\right)^{2} / D_{60} D_{10}<3$. According to the current frost susceptibility classifications used in China (Table 1), these fills are considered not susceptible to frost heave. The subgrade soil is a silty loess or a clayey loess, both classified as clayey silt (Fig. 2(b)).

The monitored maximum frost penetration in the 20102011 winter was around $1.5 \mathrm{~m}$ at the centre of the embankment (Fig. 3). The predicted maximum frost depth under cold winter conditions remains in the coarse fill (Liu et al., $2011,2012)$. The original groundwater table is located below

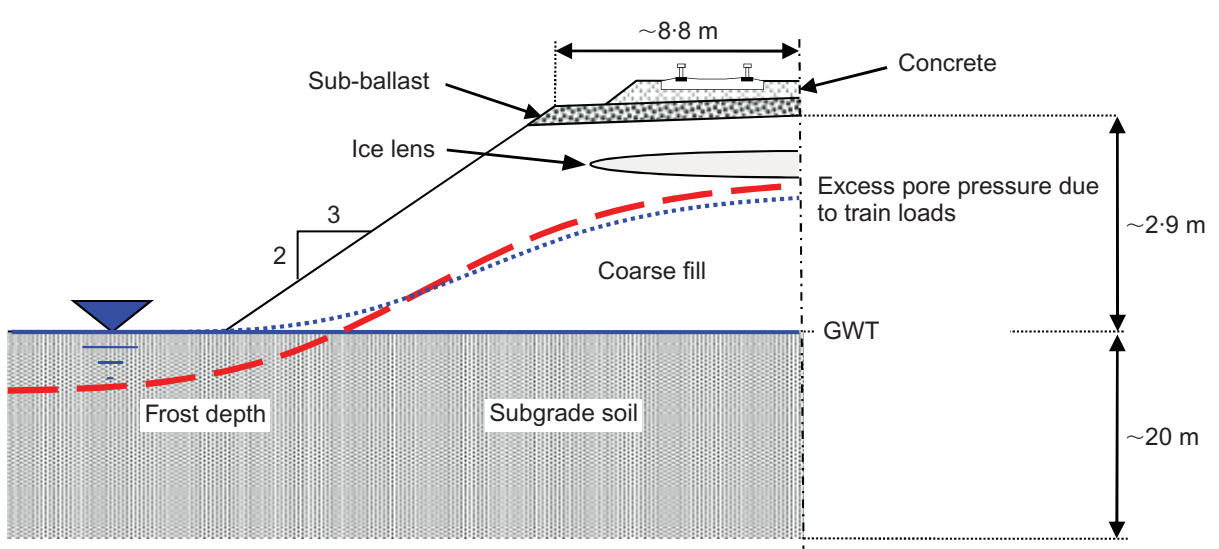

Fig. 1. Schematic view of high-speed railway embankment and mechanism of pumpingenhanced frost heave 


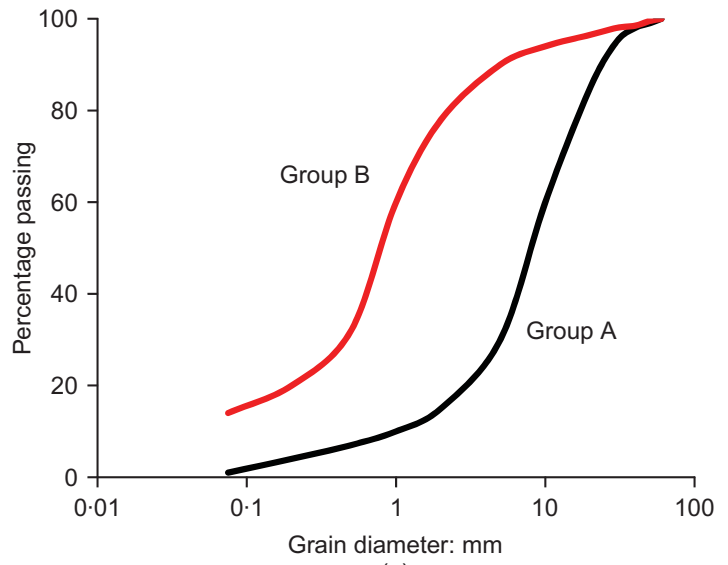

(a)

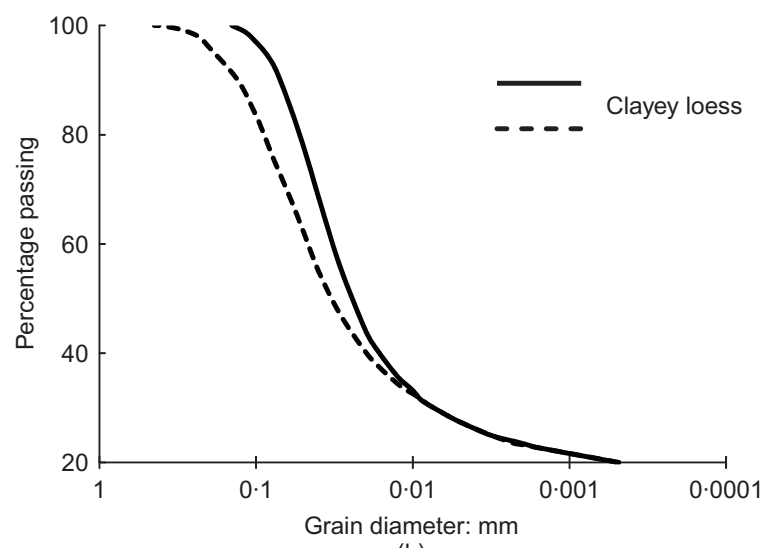

(b)

Fig. 2. Grain-size distributions of: (a) high-speed embankment fills; (b) subgrade soil

the coarse fill (Fig. 1). Field measurements showed that the frost heave in the 2010-2011 winter was of the order of $2 \mathrm{~mm}$ (Liu et al., 2011). However, the actual monitored heave within the first 3 months of the 2012-2013 winter has reached $20 \mathrm{~mm}$ at maximum. It is difficult to explain this amount of heave in coarse materials with little water using existing frost heave theories.

The proposed simple theory of frost heave is as follows. The cyclic loads of high-speed trains cause a build-up of excess pore water pressure within the subgrade fine soil below the original groundwater table. This excess pore water pressure cannot easily dissipate during freezing seasons, as the layer of soil above the frost front freezes, and its permeability is reduced (Fig. 1). The excess pore pressure then facilitates water flow towards the frost front, and feeds the formation of an ice lens there. As a consequence, frost heave occurs in the coarse fill above the groundwater table. The frost heave that occurs under this mechanism will have a profile similar to that of the excess pore pressure distribution: that is, the maximum heave occurs along the centreline of the railway embankment (Fig. 1). This heaving mechanism is referred to in this paper as pumping-enhanced frost heave.

The observed frost depth in the Ha-Da-Shian railway embankments is typically $1.0-2.0 \mathrm{~m}$ within the coarse fill (Liu et al., 2011, 2012). The total thickness of the coarse fill and the sub-ballast is $3.5 \mathrm{~m}$. Therefore it requires an excess pore water pressure of $\sim 14 \mathrm{kPa}$ to bring the water table to the frost front. This is indeed a possible excess pore pressure that can be developed by cyclic train loads. For example, Wong et al. (2006) reported field monitoring of excess pore pressures during the passage of slow trains $(40-60 \mathrm{~km} / \mathrm{h})$. They found that the maximum excess pore pressure reached $38.9 \mathrm{kPa}$ under an axle load of $350 \mathrm{kN}$ or $24.2 \mathrm{kPa}$ under an axle load of $140 \mathrm{kN}$. The maximum pore pressure occurred at a depth of $2 \cdot 5-3 \mathrm{~m}$, directly below the train tracks. They also found that the monitored excess pore pressures are all above the theoretical values estimated using the Skempton equation (Skempton, 1954).

Alobaidi \& Hoare (1996) conducted laboratory tests to simulate the excess pore pressure build-up at the interface of the sub-base and subgrade in highway embankments, and the observed excess pore pressures are of the same order of magnitude as the applied cyclic stress increments. Kettil et

Table 1. Frost susceptibility classifications used in Chinese railway systems

\begin{tabular}{|c|c|c|c|}
\hline Fill & Fines content $(<0.075 \mathrm{~mm})$ : \% & Water content: $\%$ & Frost susceptibility \\
\hline \multicolumn{4}{|c|}{ Classification according to Liu et al. (2011) } \\
\hline $\begin{array}{l}\text { Group A } \\
\text { Group B }\end{array}$ & $\begin{array}{c}\leqslant 5 \\
<5 \\
5-15 \\
15-30\end{array}$ & & $\begin{array}{l}\text { Not susceptible } \\
\text { Not susceptible } \\
\text { Weakly susceptible } \\
\text { Susceptible }\end{array}$ \\
\hline \multicolumn{4}{|c|}{ Classification according to Ye et al. (2007) } \\
\hline Gravel & $\begin{array}{c}\leqslant 15 \\
15-30 \\
>30\end{array}$ & $\begin{array}{c}\leqslant 12 \\
12-18\end{array}$ & $\begin{array}{l}\text { No frost heave } \\
\text { No frost heave } \\
\text { Little frost heave } \\
\text { Medium frost heave }\end{array}$ \\
\hline Coarse to medium sand & $\begin{array}{l}\leqslant 5 \\
5-15 \\
>15\end{array}$ & $\begin{array}{l}\leqslant 12 \\
>12 \\
\leqslant 12 \\
12-18\end{array}$ & $\begin{array}{l}\text { No frost heave } \\
\text { No frost heave } \\
\text { Little frost heave } \\
\text { No frost heave } \\
\text { Little frost heave }\end{array}$ \\
\hline Fine sand & $\begin{array}{c}\leqslant 5 \\
5-15\end{array}$ & $\begin{array}{c}\leqslant 12 \\
12-18 \\
\leqslant 14 \\
14-19 \\
19-23\end{array}$ & $\begin{array}{l}\text { No frost heave } \\
\text { No frost heave } \\
\text { Little frost heave } \\
\text { No frost heave } \\
\text { Little frost heave } \\
\text { Medium frost heave }\end{array}$ \\
\hline
\end{tabular}


Temperature: ${ }^{\circ} \mathrm{C}$

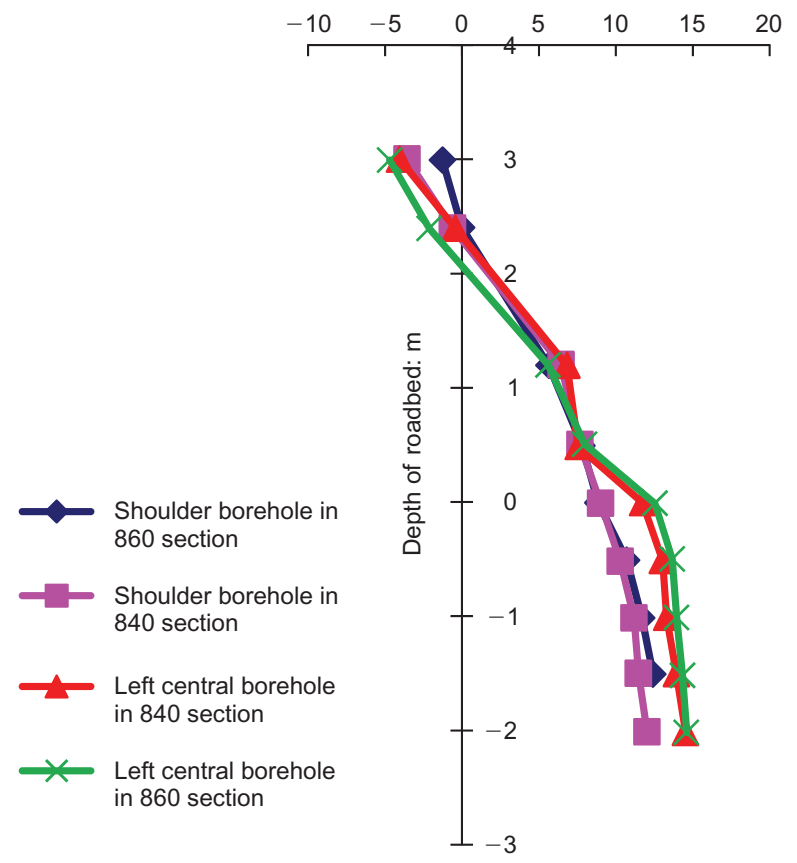

(a)

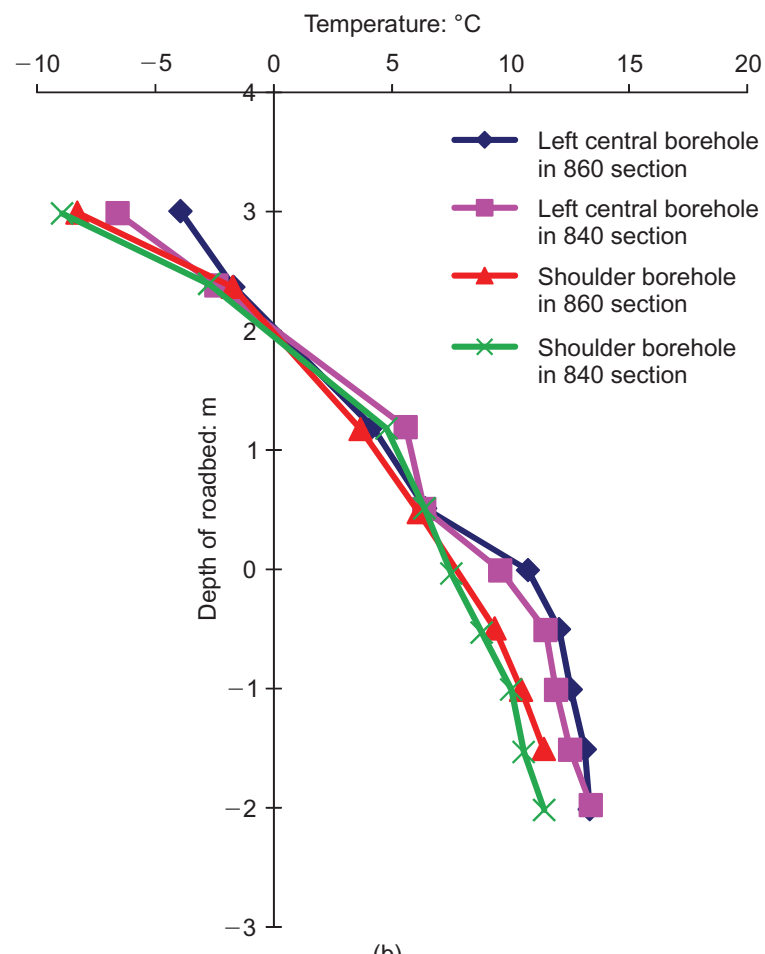

(b)

Fig. 3. Monitored temperature profiles in railway embankment in 2010-2011 winter (after Liu et al., 2012): (a) 1 January 2011; (b) 29 January 2011

al. (2008) simulated the coupled hydromechanical response of soils to the passage of high-speed trains $(180 \mathrm{~km} / \mathrm{h})$, and obtained a maximum excess pore pressure of $18 \mathrm{kPa}$ when the equivalent pressure from the train loads varied between $20 \mathrm{kPa}$ and $35 \mathrm{kPa}$. In another numerical analysis of railway embankments subjected to train loads, Li et al. (2012) predicted that the maximum excess pore pressure will vary between $20 \%$ and $40 \%$ of the initial effective vertical stress in the soil underlying a $4.4 \mathrm{~m}$ high embankment, or about $40-60 \%$ of the major principal stress increment caused by the train loads. The train speed considered is $94 \mathrm{~km} / \mathrm{h}$ on the Qinghai-Tibet railway.

\section{EXCESS PORE PRESSURE DUE TO CYCLIC TRAIN LOADS}

Soils are typical elasto-plastic materials. A closed cycle of loading and unloading usually results in a permanent volumetric strain under drained conditions, or a pore pressure increment under undrained conditions (Fig. 4). As the number of cycles increases, the pore pressure increment (i.e. the excess pore pressure) gradually increases, and tends to stabilise at a constant value. The final value of the excess pore pressure depends on a number of factors like the initial stress state, the frequency and magnitude of the cyclic loads, the soil compressibility and permeability.

There is a rich literature of empirical equations that predict the excess pore pressure build-up in soils subjected to cyclic loads. Most of these equations are based on earthquake loads or laboratory dynamic triaxial tests. For example, one such equation, attributable to Seed \& Lee (1966), is

$$
u=\sigma_{0}^{\prime}\left[\frac{2}{\pi} \arcsin \left(\frac{N}{N_{1}}\right)^{\theta / 2}\right]
$$

where $u$ is the excess pore pressure corresponding to stress cycle $N ; N_{1}$ is the number of stress cycles that lead to full liquefaction of the soil, and is a function of the dynamic load amplitude, its frequency and soil properties; $\sigma_{0}^{\prime}$ is the initial (isotropic) effective stress; and $\theta$ is a soil parameter. Equation (1) was based on experimental results obtained from dynamic triaxial tests. It is difficult to apply such an equation to predict the excess pore pressure caused by train loads, as these loads may not lead to full liquefaction of the foundation soil, even if the number of stress cycles approaches infinity. In addition, trains loads have different frequencies and magnitudes from those of earthquake loads.

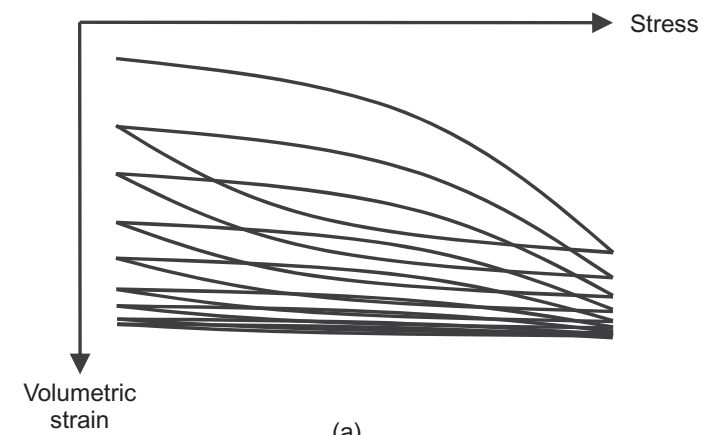

(a)

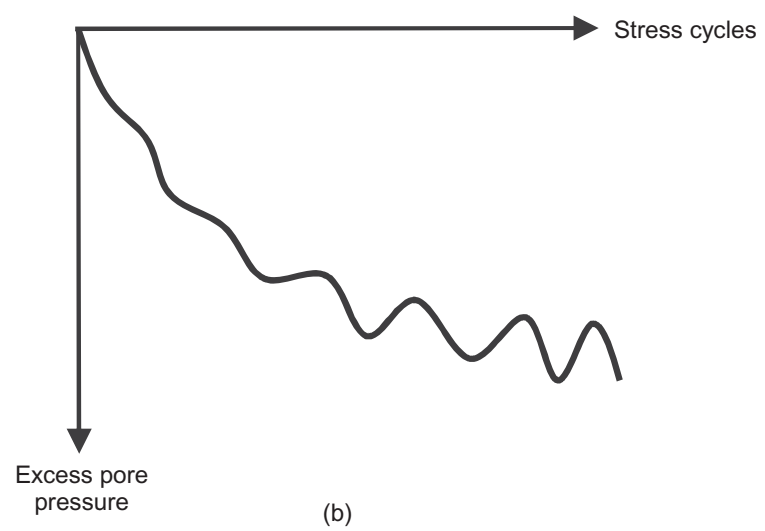

Fig. 4. Soil response to cyclic loads under (a) drained and (b) undrained conditions 
The development of excess pore water pressure under cyclic loads can also be predicted using appropriate elastoplastic constitutive models. Classical elasto-plastic models that simulate reloading following unloading as a purely elastic response cannot usually capture the excess pore pressure build-up due to cyclic loads. On the other hand, constitutive models that predict accumulated plastic volumetric strain in a drained soil subjected to cyclic loads will also predict the excess pore pressure build-up in the undrained soil. Such models include the bounding surface types of model (Dafalias, 1986), hypoplasticity models (Kolymbas, 1991) and generalised plasticity models (Pastor et al., 1990). These models can be implemented in the finite-element method by way of the consolidation equations for porous media, and can then be used to solve the displacements and pore pressures in boundary value problems subjected to dynamic loads. A similar approach is based on Biot's theory of dynamic poroelasticity, where the excess pore pressure is related to the volumetric strain of the elastic porous medium and the volumetric strain of bulk water by way of the soil and water compressibility (Biot, 1956; Jin et al., 2004; Cai et al., 2008). In either case, multidimensional numerical analysis is required to obtain the excess pore pressure induced by train loads. These advanced methods may provide the ultimate approaches of analysis, but this paper seeks a simpler approach that can be integrated into a frost heave model.

Skempton (1954) proposed a simple method to calculate the pore pressure increment caused by stress increments

$$
\Delta u=B\left[\Delta \sigma_{3}+A\left(\Delta \sigma_{1}-\Delta \sigma_{3}\right)\right]
$$

where $\Delta u$ is the pore pressure increment or excess pore pressure corresponding to the major principal stress increment $\left(\Delta \sigma_{1}\right)$ and minor principal stress increment $\left(\Delta \sigma_{3}\right)$, and $A$ and $B$ are two soil parameters. For saturated soils, $B=1$. Wong et al. (2006) showed that the minor principal stress increment $\left(\Delta \sigma_{3}\right)$ caused by train load is negligible. For an isotropic elastic soil, $A=1 / 3$.

Wong et al. (2006) showed that equation (2) with $A=1$ / 3 and $B=1$ significantly underestimates the monitored excess pore pressure caused by train loads. Numerical results by Li et al. (2012) showed that the maximum excess pore pressure is about $40-60 \%$ of the major principal stress increment associated with train loads. The excess pore pressures considered in Wong et al. (2006) and Li et al. (2012) were both in the subgrade soil at depths of $2.5-5 \mathrm{~m}$ below the train tracks, similar to the depth studied in this paper (Fig. 1). Konrad et al. (2007) and Hendry et al. (2013) also reported in situ excess pore pressure data caused by train loads. Their data showed that the excess pore pressures did not always disappear after passage of the train, particularly those at sufficient depth (for example the excess pore pressure at $3.5 \mathrm{~m}$ depth in Konrad et al., 2007).

It should be noted that equation (1) predicts the residual excess pore pressure when the cyclic external load is removed, whereas equation (2) predicts the instantaneous excess pore pressure caused by stress increments. In highspeed railway embankments the relative importance of these two types of pore pressure depends on the frequency of the train passage, the actual cooling rate in and the permeability of the freezing soil. It is likely that the residual excess pore pressure will play a more significant role in frost heave, as freezing and heaving are generally slower processes than the passage of trains.

\section{FROST HEAVE MODEL INCORPORATING PUMPING EFFECTS}

There are several frost heave models in the literature (e.g. Konrad \& Morgenstern, 1980, 1981; O’Neill \& Miller, 1985; Nishimura et al., 2009). The frost heave model used in this paper is based on Sheng et al. (1995a, 1995b, 2013). It assumes the existence of a frozen fringe (Miller, 1972). The frozen fringe is the area between the growing ice lens and the warmest ice particles. The actual thickness of the frozen fringe will depend on the soil properties, temperature gradients and overburden pressure. In coarse-grained soils such as sand its thickness is almost zero, whereas its thickness can be substantial $(>5 \mathrm{~cm})$ in clays under high overburden pressure. The physics of heat and mass transfer and the thermodynamics of ice lensing within the frozen fringe constitute the essence of the frost heave model.

The essential concepts in the frost heave model of Sheng et al. (2013) are as follows.

(a) The soil profile consists of an arbitrary number of soil layers.

(b) The temperature gradient in each soil layer is linear, but may vary with time.

(c) The permeability of the frozen fringe decreases exponentially as a function of the temperature.

(d) The frozen fringe is always saturated by water or ice.

(e) The rates of water flow in the frozen fringe and in each unfrozen soil layer are constant in space, but may vary with time.

(f) The pore ice particles in the frozen fringe are connected to the warmest ice lens as a rigid body.

(g) A new ice lens appears in the frozen fringe when and where the effective stress approaches zero.

(h) The Clapeyron equation is used to describe the pressures and temperature at the water/ice interface.

(i) At any time there is only one ice lens growing (old ice lenses stops growing once a new ice lens forms).

(j) The rate of frost heave is the same as the rate of ice lens growth.

The above concepts, the heat and mass transfer equations, the ice lens initiation criterion and the computation of material parameters involved in the frost heave model are implemented in a computer program called PCHeave (Sheng et al., 1995a, 2013). This program will be used in this paper, and the main equations in PCHeave are given in the Appendix. The only modification is the pore water pressure at the original groundwater table, which was assumed to be zero in the original model. The excess pore water pressure due to train loads can be added to this pore water pressure. The rate of water flow in the unfrozen soil $\left(v_{\mathrm{u}}\right)$ is then modified according to

$$
v_{\mathrm{u}}=\frac{k_{\mathrm{u}}}{\rho_{\mathrm{w}} \boldsymbol{g}}\left[\frac{u\left(x_{\mathrm{gw}}\right)-u\left(x_{\mathrm{f}}\right)}{x_{\mathrm{f}}-x_{\mathrm{gw}}}+\rho_{\mathrm{w}} \boldsymbol{g}\right]
$$

where $k_{\mathrm{u}}$ is the effective permeability of the unfrozen soil between the frost front and the groundwater table, $g$ is the acceleration of gravity, $x_{\mathrm{gw}}$ is the location of the groundwater table, $u\left(x_{\mathrm{gw}}\right)$ is the pore water pressure at the groundwater table, and $u\left(x_{\mathrm{f}}\right)$ is the pore water pressure at the frost front $\left(x_{\mathrm{f}}\right)$. The pore water pressure at the groundwater table is the excess pore pressure caused by the cyclic train loads, that is, equation (2).

In addition, the rising of the groundwater table due to the train-induced excess pore pressure (Fig. 1) will cause saturation of the soil originally above the groundwater table. As a consequence, the permeability of the soil will change. The permeability of a partially saturated soil in the unfrozen 
state is approximated by a given saturated permeability (Hillel, 1971) as

$$
k=k_{\mathrm{sat}} S_{\mathrm{r}}^{m}=k_{\mathrm{sat}}\left(\frac{n-I}{n}\right)^{m}
$$

where $k_{\mathrm{sat}}$ is the saturated permeability; $S_{\mathrm{r}}$ is the degree of saturation; $m$ is a soil parameter, and a default value of 9 is used; $n$ is the porosity of the soil; and $I$ is the volumetric ice content.

\section{EFFECT OF TRAIN LOADS ON FROST HEAVE}

According to the Code for Design High-Speed Railway (China Ministry of Railways, 2009), the load from the train-track system can be exchanged into soil columns of equivalent heights. The basic idea of this exchange is that the dynamic load from the train-track system can be approximated by an equivalent static load. This static load is assumed to act uniformly over a distribution width on the ground surface, and is then considered in the embankment settlement and stability analysis. The static load is given in terms of column heights of the foundation soil. Table 1 gives the equivalent soil column height for the specific train and track systems.

The soil columns listed in Table 2 represent a vertical stress increment between $50 \mathrm{kPa}$ and $56 \mathrm{kPa}$. According to equation (2) with $A=0.5$ and $B=1$, this stress increment will cause an excess pore pressure between $25 \mathrm{kPa}$ and $28 \mathrm{kPa}$.

A three-layered soil profile for high-speed railway embankments is shown in Fig. 5. The upper layer is a $40 \mathrm{~cm}$ thick sub-ballast, which is treated as frost non-susceptible in PCHeave. Therefore the frost penetration and frost heave in this layer are ignored. The middle layer is $290 \mathrm{~cm}$ thick coarse fill, with an initial water content of $5 \%$ and an initial degree of saturation of $70 \%$. The lower layer is a clayey silt with a saturated water content of $30 \%$. The original groundwater table is located at the depth of $350 \mathrm{~cm}$. The normal frost penetration depth is within the coarse fill. The soil properties and boundary conditions are also shown in Fig. 5. The material parameters are assumed typical values of the related soils (Liu et al., 2012). The freezing index of $1000^{\circ} \mathrm{C}$ days also represents a typical winter length and coldness in north-eastern China. Because the actual case of Ha-Da-Shian is not yet open for analysis or publication, this paper will only demonstrate the effect of the excess pore pressure caused by train loads on the computed heave. It is therefore acceptable to use assumed values of material parameters and boundary conditions.

Under the conditions given in Fig. 5, the maximum frost depth after $2400 \mathrm{~h}$ of freezing is $312 \mathrm{~cm}$, and hence the frost front is located in the coarse fill. The computed frost heave at the 2400th hour is only $0.4 \mathrm{~mm}$, which is well below the displacement tolerance of high-speed railways in China. Therefore, without considering the excess pore pressure, no significant frost heave is expected to occur in such a railway

Table 2. Exchange of train-track loads into equivalent soil columns (China Ministry of Railways, 2009)

\begin{tabular}{|c|c|c|c|c|c|c|c|c|}
\hline \multirow[t]{3}{*}{ Train live load type } & \multirow[t]{3}{*}{ Axle load: $\mathrm{kN}$} & \multirow[t]{3}{*}{ Track type } & \multirow[t]{3}{*}{ Distr. width: $\mathrm{m}$} & \multicolumn{5}{|c|}{ Height of soil column: m } \\
\hline & & & & \multicolumn{5}{|c|}{ Soil unit weight: $\mathrm{kN} / \mathrm{m}^{3}$} \\
\hline & & & & 18 & 19 & 20 & 21 & 22 \\
\hline ZK live load & 200 & $\begin{array}{l}\text { CRTS I (ballastless) } \\
\text { CRTS I (double block ballastless) } \\
\text { CRTS II (ballastless) } \\
\text { Ballast }\end{array}$ & $\begin{array}{l}3 \\
3 \cdot 4 \\
3 \cdot 25 \\
3 \cdot 4\end{array}$ & $\begin{array}{l}3 \cdot 1 \\
2 \cdot 8 \\
2 \cdot 9 \\
3 \cdot 0\end{array}$ & $\begin{array}{l}2 \cdot 9 \\
2 \cdot 7 \\
2 \cdot 7 \\
2 \cdot 8\end{array}$ & $\begin{array}{l}2 \cdot 8 \\
2 \cdot 6 \\
2 \cdot 6 \\
2 \cdot 7\end{array}$ & $\begin{array}{l}2 \cdot 6 \\
2 \cdot 4 \\
2 \cdot 5 \\
2 \cdot 6\end{array}$ & $\begin{array}{l}2 \cdot 5 \\
2 \cdot 3 \\
2 \cdot 3 \\
2 \cdot 4\end{array}$ \\
\hline
\end{tabular}

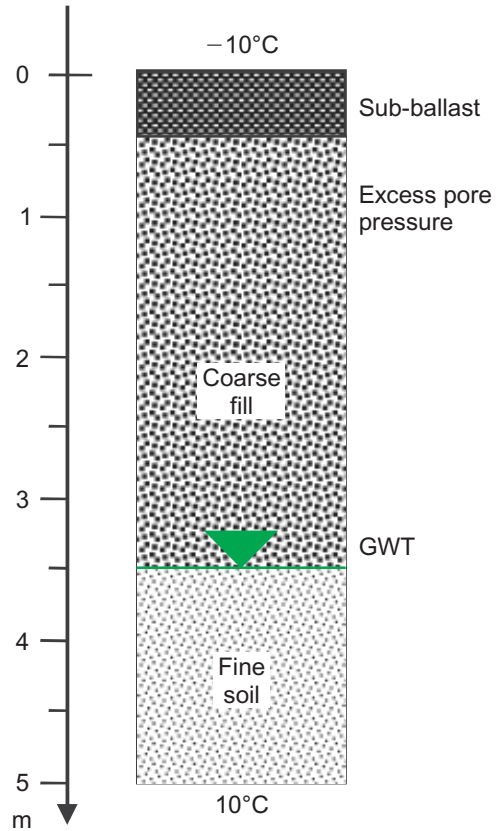

\begin{tabular}{l|c|c|c}
\hline & Sub-ballast & $\begin{array}{c}\text { Coarse } \\
\text { fill }\end{array}$ & $\begin{array}{c}\text { Fine } \\
\text { soil }\end{array}$ \\
\hline$\lambda: \mathrm{W} / \mathrm{mK}$ & 3 & 3 & 3 \\
\hline$w_{0}: \%$ & 5 & 5 & 30 \\
\hline$\rho_{\mathrm{d}}: t / \mathrm{m}^{3}$ & $2 \cdot 2$ & 2 & $1 \cdot 5$ \\
\hline$S_{\mathrm{r}}: \%$ & - & 70 & 100 \\
\hline$k_{\mathrm{sat}}: \mathrm{m} / \mathrm{s}$ & - & $10^{-4}$ & $10^{-7}$ \\
\hline$w_{\mathrm{u}} / \mathrm{w}_{0}:-1^{\circ} \mathrm{C}, \%$ & - & 10 & 30 \\
\hline
\end{tabular}

Freezing index $=10 \times 100=1000^{\circ} \mathrm{C}$ days

Fig. 5. Soil profile of high-speed railway embankment, and material properties 
embankment. Test runs also indicate that, to generate a heave of $5 \mathrm{~mm}$ or larger, the saturated water content in the coarse fill should be at least $10 \%$ in mass, and the initial degree of saturation should be at least $90 \%$. These conditions are usually restricted in constructing high-speed railway embankments.

However, the situation changes dramatically if the traininduced excess pore pressure is included in the frost heave computation. For example, a modest excess pore pressure of $10 \mathrm{kPa}$ will result in a heave of $5.3 \mathrm{~mm}$ (Fig. 6). An excess pore pressure of $25 \mathrm{kPa}$ will lead to a heave of $22.6 \mathrm{~mm}$, which is well above the design limit $(15 \mathrm{~mm})$. Fig. 6 shows the computed heave and frost depth against the assumed excess pore water pressure generated in the foundation soil. In obtaining the results, the train-induced excess pore pressure was assumed to be constant during the whole freezing period. While this is a coarse assumption, the results shown in Fig. 6 are indicative. What is more significant is that the traininduced excess pore pressure is likely to be non-uniform across the section of the embankment (as shown in Fig. 1), possibly resulting in maximum heave under the centre of the embankment. It should be noted that the one-dimensional model used here essentially assumes that the whole groundwater table is raised up and the lateral supply of water is unlimited. This is another coarse assumption. To capture the real frost heave profile over the cross-section, at least a two-dimensional frost heave model is required. Fig. 6 also shows that the computed frost depth decreases as the excess pore pressure increases.

Figure 7 shows the developments of frost heave and frost depth with time. The computed results without considering excess pore pressure are compared against those with an excess pore pressure of $25 \mathrm{kPa}$. In the case of no excess pore pressure, both the heave rate and the rate of frost penetration stabilise with time. In the case of the constant excess pore pressure, the heave rate is almost constant over the time period, while the frost penetration stabilises very early. Although the results in Fig. 7 are only indicative, it is alarming to observe that the pumping-enhanced heave continues over the entire winter, as long as the train runs and the excess pore pressure remains in the soil. Because of the

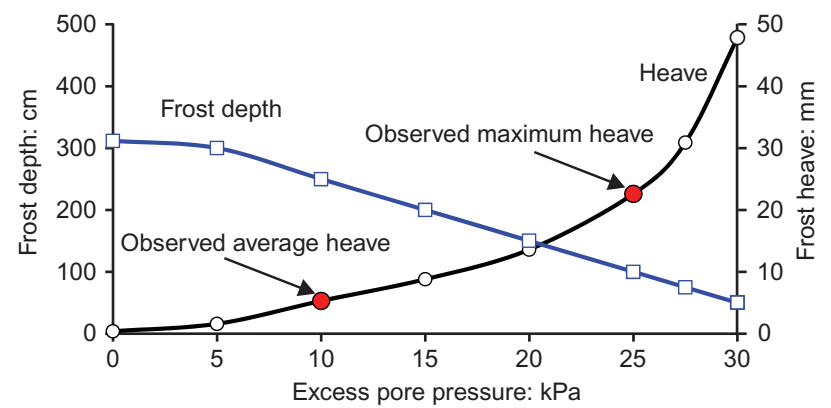

Fig. 6. Effect of excess pore pressure on frost heave and frost depth (freezing index $=1000^{\circ} \mathrm{C}$ )

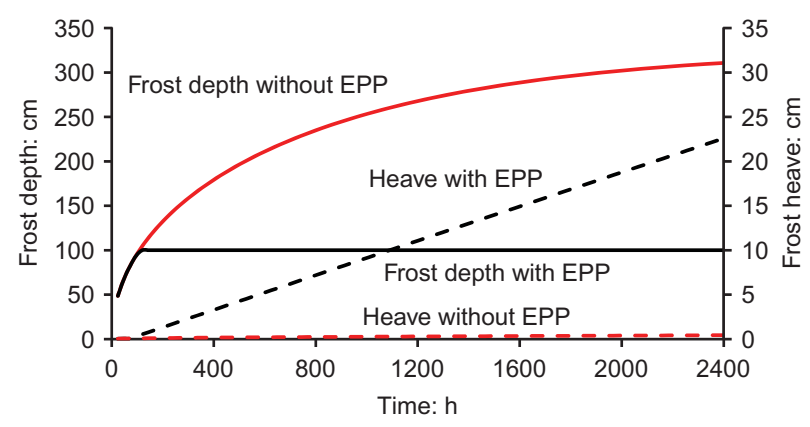

Fig. 7. Time history of computed frost heave and frost depth with or without excess pore pressure (EPP) assumed constant excess pore pressure, the frost penetration stabilises early on at the equivalent groundwater table. The groundwater from both sides of the embankment continues to feed the ice formation at the frost front, leading to a maximum heave along the centreline of the embankment. It should be noted that the change of the thermal conductivity due to ice formation in the frozen soil is considered in the frost heave model (see Appendix).

The ice-lensing characteristics with and without excess pore pressure are shown in Fig. 8. Without excess pore pressure, only very thin ice lenses form in the coarse soil, and the total thickness of these lenses is negligible $(0.4 \mathrm{~mm})$. By contrast, a thick ice lens forms when an excess pore pressure of $25 \mathrm{kPa}$ is assumed. The thickness of this lens at the 2400th hour is $22.6 \mathrm{~mm}$. As the growth of this ice lens is continuously fed by the water flow driven by the constant excess pore pressure, frost heave continues at an approximately constant rate.

\section{ENGINEERING IMPLICATIONS OF PUMPING- \\ ENHANCED HEAVE}

As the pumping-enhanced frost heave is driven by the excess pore pressure associated with cyclic train loads, common engineering practices in designing frost heave
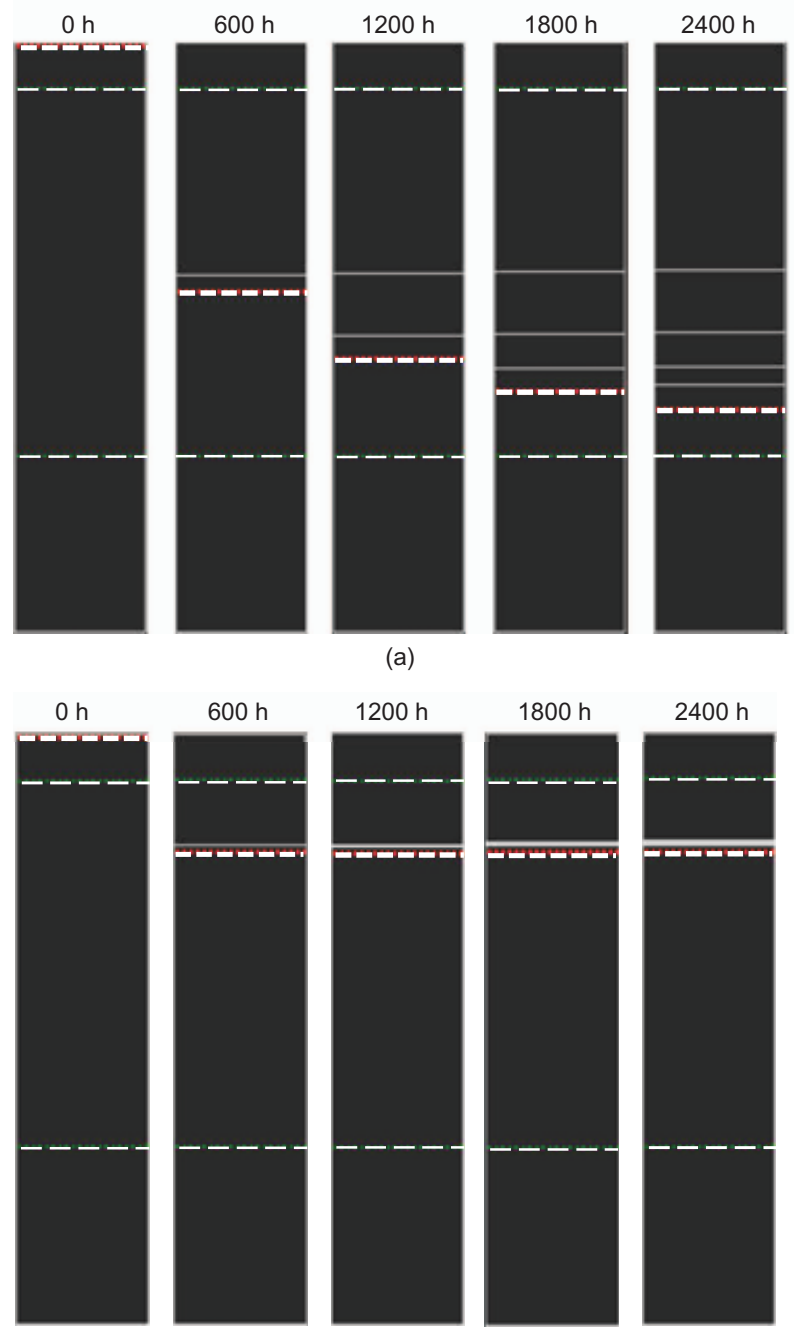

(a)
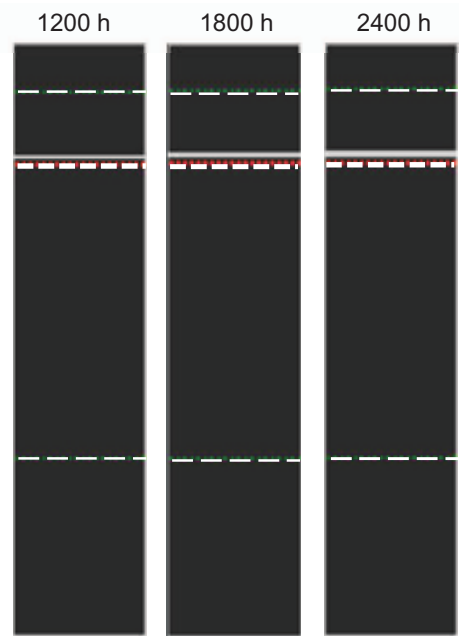

Fig. 8. Ice-lensing characteristics in soil column (short dashed lines, frost front; solid lines, ice lenses; long dashed lines, material boundaries): (a) without excess pore pressure; (b) with $25 \mathrm{kPa}$ excess pore pressure 
mitigation measures in seasonally frozen ground will be challenged. For example, maintaining the frost penetration depth within the frost-non-susceptible coarse layer, or keeping the groundwater table below the maximum frost depth, does not necessarily work, as demonstrated in the above example. Placing drains simply above or below the coarse sub-base would not eliminate the frost heave either, if the excess pore pressure in the subgrade soil cannot dissipate effectively through these drains. It should also be noted that the effectiveness of drains will be affected by freezing in winter seasons.

The most effective measure for mitigating the pumpingenhanced frost heave would seem to eliminate possible water flow towards the frost front by placing a layer of impermeable material, such as impervious geotextile, below the maximum frost depth. However, there can be side effects of such an impervious layer on the excess pore pressure buildup. Alobaidi \& Hoare (1996) observed that placing a layer of geotextile at the subgrade/sub-base interface further increases the excess pore pressure in the subgrade. The continuous build-up of excess pore pressure in the subgrade can degrade the strength of the soil, and hence lead to stability problems in the embankment. Therefore the overall effects of placing impervious material at the subgrade/ sub-base interface must be carefully investigated. In addition, the service life and leakages of the impervious geotextile will play an important role in its effectiveness in controlling the water flow and hence the frost heave.

A possible mitigation measure against pumping-enhanced frost heave is to place a layer of gravel above the groundwater table, but below the maximum frost depth (Fig. 9). Drain pipes can be installed in the gravel layer. Proper measures must be taken so that these drain pipes are not blocked during winter seasons. The gravel layer and drain pipes will act to prevent the dissipation of excess pore pressure towards the frost front. It is important to realise these implications when designing high-speed railway embankments where vertical displacement is strictly limited.

\section{CONCLUSIONS}

This paper presents a simple potential mechanism for the interaction between train loads and frost heave, in an attempt to explain the unexpected frost heave observed in high-speed railway embankments. It should be stressed that this paper is not a case study, and the conclusions derived here remain provisional upon further experimental evidence. One of the main outcomes from this study is hopefully to stimulate further laboratory, field and numerical investigation of a very interesting problem.

It is proposed that cyclic train loads cause excess pore pressure build-up in the foundation soil, which in turn facil-

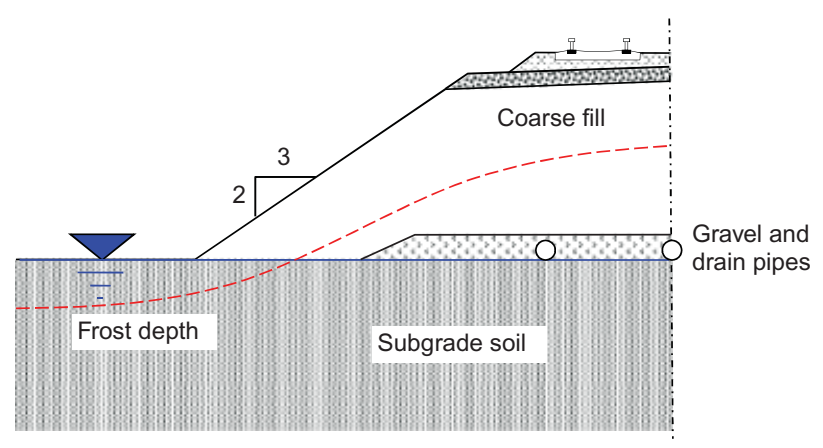

Fig. 9. Possible mitigation measure against pumping-enhanced frost heave in high-speed railway embankment itates water flow towards the frost front, feeding ice formation and hence causing continuous heave. A simple equation is used to predict the excess pore pressure caused by high-speed train loads. The excess pore pressure is then built into the frost heave model (PCHeave). Numerical examples demonstrate that the excess pore pressure dramatically affects the computed frost heave and frost penetration depth.

The proposed frost heave mechanism has profound engineering implications, and can potentially alter the design philosophy for high-speed railway embankments on seasonally frozen grounds. It challenges the common engineering practices against frost heave, such as replacing frostsusceptible soils with frost-non-susceptible coarse fills, or keeping the frost penetration depth within frost-nonsusceptible soils by insulation or backfilling, or maintaining the groundwater table below the maximum frost depth. Even placing drains above and below the coarse sub-base would not eliminate pumping-enhanced frost heave. The most effective measure is to eliminate possible water flow towards the frost front. In designing high-speed railway embankments where vertical displacement is strictly limited, it is very important to realise these implications.

The model presented in this paper for pumping-enhanced frost heave is simplistic in nature. The main purpose is to demonstrate that such a frost heave mechanism can indeed explain, at least qualitatively, the unexpected heave observed in coarse fills with little water content. The proposed mechanism, although based on well-documented phenomena in the literature, needs to be validated against laboratory tests, and perhaps against field measurements as well. It is also likely that a more accurate description of the excess pore water pressure associated with train loads will be required in order to predict pumping-enhanced frost heave better. Such a prediction can be obtained through, for example, the use of a reasonable constitutive model that captures the development of both instantaneous and residual excess pore pressures under cyclic loads. The relative importance of the instantaneous and residual excess pore pressures can then be investigated, based on such a constitutive model.

The interaction between train loads and the coupled heat and mass transfer in foundation soils is a complex process. This paper focuses only on one specific aspect, the effect of train-induced excess pore pressure on frost heave. Other aspects include, but are not limited to, the effects of impermeable frozen soils on the development of excess pore pressures, the effects of train loads on the dissipation of excess pore pressure in subgrade soils during thawing periods, the hydromechanical properties of frozen soils subjected to dynamic loads, the interaction between frost heave mitigation measures and excess pore pressure development, and the settlements due to the dissipation of excess pore pressure. These issues become particularly important for highspeed trains, which are very sensitive to track displacements. Further research on these issues is warranted.

\section{ACKNOWLEDGEMENTS}

This research was supported by National Basic Research Program of China (2013CB036201) and National Natural Science Foundation of China (grant no. 51208519).

\section{APPENDIX: ONE-DIMENSIONAL FROST HEAVE MODEL - PCHEAVE \\ Ice lens initiation}

A new ice lens is assumed to be initiated when and where the effective stress in the soil approaches zero. The effective stress is defined as 


$$
\begin{aligned}
\sigma^{\prime} & =\sigma-\frac{n-I}{n} u_{\mathrm{w}}-\frac{I}{n} u_{\mathrm{i}} \\
& =\sigma-u_{\mathrm{n}}
\end{aligned}
$$

where $\sigma$ is the total stress or the total overburden pressure, $\sigma^{\prime}$ is the effective stress, $n$ is the soil porosity, $I$ is the ice content, $u_{\mathrm{w}}$ is the pore water pressure, $u_{\mathrm{i}}$ is the pore ice pressure, and $u_{\mathrm{n}}$ is the neutral stress.

Assuming that the ice/water interface is at equilibrium, the ice pressure, water pressure and temperature are related through the Clapeyron equation

$$
\frac{u_{\mathrm{w}}}{\rho_{\mathrm{w}}}-\frac{u_{\mathrm{i}}}{\rho_{\mathrm{i}}}=L \frac{T}{T_{0}}
$$

where $\rho_{\mathrm{w}}$ is the density of liquid water, $\rho_{\mathrm{i}}$ is the density of ice, $L$ is the specific latent heat of water, $T_{0}$ is the freezing point of water in Kelvin, $T$ is the temperature at the ice/water interface in degrees Celsius, or the so-called segregational temperature.

Substituting equation (6) into equation (5) to eliminate the ice pressure leads to

$$
u_{\mathrm{n}}=\left(1-\frac{I}{n}+\frac{I}{n} \frac{\rho_{\mathrm{i}}}{\rho_{w}}\right) u_{\mathrm{w}}-L \rho_{\mathrm{i}} \frac{I}{n} \frac{T}{T_{0}}
$$

A new ice lens is initiated within the frozen fringe when and where the neutral stress reaches the total stress or the total overburden pressure.

\section{Heat and mass transfer}

Assume the location of the frozen fringe is known at time $t$. The aim is to determine the rate of heave during a small time step $\Delta t$ and the new location of the frozen fringe at time $t+\Delta t$.

The heat balance is considered for each soil layer. At the warm surface of the latest ice lens ( $x_{\mathrm{b}}$ in Fig. 10), the heat balance states that

$$
\lambda_{\mathrm{f}} \frac{T_{\mathrm{s}}-T_{\mathrm{c}}}{x_{\mathrm{c}}-x_{\mathrm{b}}}-\lambda_{\mathrm{ff}} \frac{T_{\mathrm{f}}-T_{\mathrm{s}}}{x_{\mathrm{b}}-x_{\mathrm{f}}}=\left(1-I_{\mathrm{b}}\right) V_{\mathrm{i}} \rho_{\mathrm{i}} L
$$

where $\lambda_{\mathrm{f}}$ is the effective thermal conductivity of the layer above $x_{\mathrm{b}}$, $\lambda_{\mathrm{ff}}$ is the effective thermal conductivity of the current frozen fringe, $x_{\mathrm{c}}$ is either the cold boundary of the soil profile for coarse calculation or the location of the cold boundary of the growing ice lens, $T_{\mathrm{c}}$ is the temperature at location $x_{\mathrm{c}}, x_{\mathrm{f}}$ is the location of the frost front, $T_{\mathrm{f}}$ is the temperature at location $x_{\mathrm{f}}, L$ is the specific latent heat of water, $I_{\mathrm{b}}$ is the current volumetric ice content at $x_{\mathrm{b}}, \rho_{\mathrm{i}}$ is the density of ice, and $V_{\mathrm{i}}$ is the rate of ice lensing or the rate of heave during time step $\Delta t$.

The overall heat balance for the frozen fringe can be expressed as

$$
\lambda_{\mathrm{f}} \frac{T_{\mathrm{s}}-T_{\mathrm{c}}}{x_{\mathrm{c}}-x_{\mathrm{b}}}-\lambda_{\mathrm{u}} \frac{T_{\mathrm{w}}-T_{\mathrm{f}}}{x_{\mathrm{w}}-x_{\mathrm{f}}}=\left[V_{\mathrm{i}}+\bar{I}\left(-\frac{\mathrm{d} x_{\mathrm{f}}}{\mathrm{d} t}\right)\right] \rho_{\mathrm{i}} L
$$

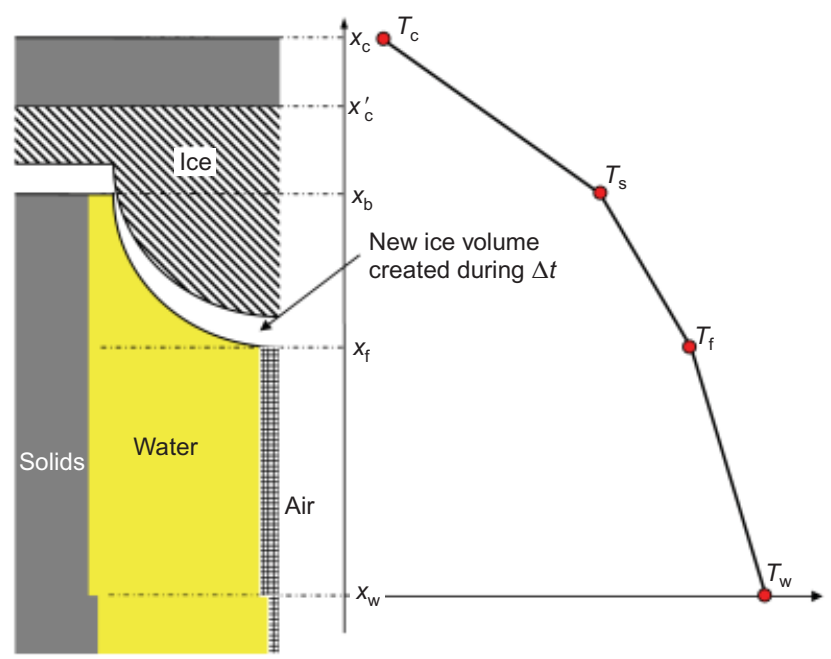

Fig. 10. Phase volumes and temperature profile around frozen fringe where $\mathrm{d} x_{\mathrm{f}} / \mathrm{d} t$ is the advancing rate of the frost front $x_{\mathrm{f}}$ or the frost penetration rate during $\Delta t$, and is negative when frost advances downwards; $\lambda_{\mathrm{u}}$ is the effective thermal conductivity of the unfrozen zone between $x_{\mathrm{f}}$ and $x_{\mathrm{w}}$ (Fig. 10); $x_{\mathrm{w}}$ is the boundary of the soil layer below the frost front; $T_{\mathrm{c}}$ is the temperature at location $x_{\mathrm{c}}$; and $\bar{I}$ is the mean ice content in the current frozen fringe.

The mass conservation at $x_{\mathrm{b}}$ requires that the water flow to $x_{\mathrm{b}}$ equals the ice mass formed there

$$
v_{\mathrm{ff}} \rho_{\mathrm{w}}=\left(1-I_{\mathrm{b}}\right) V_{\mathrm{i}} \rho_{\mathrm{i}}
$$

where $v_{\mathrm{ff}}$ denotes the rate of water flow in the frozen fringe.

The overall mass balance within the frozen fringe requires that the outflow of ice mass at $x_{\mathrm{b}}$ must balance the inflow of water mass at $x_{\mathrm{f}}$ plus the mass loss in the frozen fringe

$$
V_{\mathrm{i}} \rho_{\mathrm{i}}=v_{\mathrm{u}} \rho_{\mathrm{w}}+\left(\rho_{\mathrm{w}}-\rho_{\mathrm{i}}\right) \bar{I}\left(-\frac{\mathrm{d} x_{\mathrm{f}}}{\mathrm{d} t}\right)
$$

where $v_{\mathrm{u}}$ is the rate of water flow in the unfrozen soil below the frost front.

In the case where the frost front is above the groundwater table, the rate of water flow in the unfrozen soil $\left(v_{\mathrm{u}}\right)$ can be determined by Darcy's law as

$$
v_{\mathrm{u}}=\frac{k_{\mathrm{u}}}{\rho_{\mathrm{w}} \boldsymbol{g}}\left[\frac{u_{\mathrm{w}}\left(x_{\mathrm{gw}}\right)-u_{\mathrm{w}}\left(x_{\mathrm{f}}\right)}{x_{\mathrm{f}}-x_{\mathrm{gw}}}+\rho_{\mathrm{w}} \boldsymbol{g}\right]
$$

where $k_{\mathrm{u}}$ is the effective permeability of the unfrozen soil between the frost front and the groundwater table, $g$ is the acceleration of gravity, $x_{\mathrm{gw}}$ is the location of the groundwater table, $u_{\mathrm{w}}\left(x_{\mathrm{gw}}\right)$ is the pore water pressure at the groundwater table, and $u_{\mathrm{w}}\left(x_{\mathrm{f}}\right)$ is the pore water pressure at the frost front $\left(x_{\mathrm{f}}\right)$. The pore water pressure at the groundwater table is usually zero, unless an excess pore pressure is considered.

The pore water pressure in the frozen fringe can be derived from the assumed constant water flow rate in the frozen fringe, the assumed permeability function and the generalised Clapeyron equation as

$$
\begin{aligned}
u_{\mathrm{w}}(x)= & L \rho_{\mathrm{w}} \frac{T}{T_{0}}+\sigma \frac{\rho_{\mathrm{w}}}{\rho_{\mathrm{i}}} \\
& +v_{\mathrm{ff}} \rho_{\mathrm{w}} \boldsymbol{g} \frac{\exp \left(b x_{\mathrm{b}}-b x_{\mathrm{f}}\right)-\exp \left(b x-b x_{\mathrm{f}}\right)}{b k_{\mathrm{u}}} \\
& +\rho_{\mathrm{w}} \boldsymbol{g}\left(x_{\mathrm{b}}-x\right)
\end{aligned}
$$

where $\sigma$ is the overburden pressure at location $x_{\mathrm{b}}, k_{\mathrm{u}}$ is the saturated permeability of the soil within the frozen fringe (before freezing), and $b$ is a parameter that will be determined below.

Equations (8)-(13) form the basis of the frost heave model. Provided the location of the frozen fringe $\left(x_{\mathrm{f}}, x_{\mathrm{b}}\right)$, the ice content $(I)$ within the frozen fringe and the material parameters involved are known, they can be solved by iteration for the six unknowns $T_{\mathrm{s}}, V_{\mathrm{i}}$, $\mathrm{d} x_{\mathrm{f}} / \mathrm{d} t, v_{\mathrm{ff}}, v_{\mathrm{u}}$ and $u_{\mathrm{w}}(x)$.

If the frost front penetrates below the groundwater table, the pore water pressure at the frost front is then determined by

$$
u_{\mathrm{w}}\left(x_{\mathrm{f}}\right)=\left(x_{\mathrm{gw}}-x_{\mathrm{f}}\right) \rho_{\mathrm{w}} \boldsymbol{g}
$$

In this case, equations (8), (9), (10) and (13) are still valid. Together with equation (14), the five equations are solved for the five unknowns $T_{\mathrm{s}}, V_{\mathrm{i}}, \mathrm{d} x_{\mathrm{f}} / \mathrm{d} t, v_{\mathrm{ff}}$ and $u_{\mathrm{w}}(x)$.

So far, the governing equations have been established based on knowledge of the location of the frozen fringe. Now follows a discussion on how to locate the frozen fringe at each time step. If the frozen fringe $\left(x_{\mathrm{f}}, x_{\mathrm{b}}\right)$ is known at time $t$, the frost penetration rate $\mathrm{d} x_{\mathrm{f}} / \mathrm{d} t$ can be determined, and the new position of the frost front at time $t+\Delta t$ is $x_{\mathrm{f}}+\left(\mathrm{d} x_{\mathrm{f}} / \mathrm{d} t\right) \Delta t$. The position of the warm surface of the latest ice lens, $x_{\mathrm{b}}$, remains fixed unless a new ice lens appears within the frozen fringe. A new ice lens appears when and where the effective stress vanishes.

\section{Material parameters}

The governing equations contain several material parameters that have to be determined. They include the effective thermal conductivity and the permeability of a multilayer structure, the thermal conductivity and the permeability of a multiphase material, and the ice content of the frozen fringe. 
The effective value of a conductive parameter of a stratified profile (i.e. the effective thermal conductivity and the effective permeability) can be represented by the harmonic mean

$$
\bar{\Lambda}=h\left(\frac{h_{1}}{\Lambda_{1}}+\frac{h_{2}}{\Lambda_{2}}+\cdots\right)
$$

where $\bar{\Lambda}$ denotes the effective value to be determined, $h$ is the total thickness, $h_{i}$ is the thickness of the $i$ th layer, and $\Lambda_{i}$ is the parameter of the $i$ th layer.

The thermal conductivity of a soil saturated by water and ice can be expressed by the geometric mean

$$
\lambda_{\mathrm{sat}}=\lambda_{\mathrm{s}}^{1-n} \lambda_{\mathrm{w}}^{n-I} \lambda_{\mathrm{i}}^{I}
$$

where subscripts $\mathrm{s}, \mathrm{w}$ and $\mathrm{i}$ stand for soil solid, water and ice respectively. The thermal conductivity of an unsaturated soil is given as

$$
\lambda=\left(\lambda_{\text {sat }}-\lambda_{\text {dry }}\right) K_{\mathrm{e}}+\lambda_{\text {dry }}
$$

where $\lambda_{\text {dry }}$ is the thermal conductivity of the dry soil, and $K_{\mathrm{e}}$ is a parameter called the Kersten number (Kersten, 1949; cited in Farouki, 1986).

The permeability of a partially frozen soil is a function of the temperature and the soil. The specific function used here is

$$
\begin{aligned}
k_{\mathrm{ff}} & =k_{\mathrm{u}} \exp \left(c T-c T_{\mathrm{f}}\right) \\
& =k_{\mathrm{u}} \exp \left(-b x+b x_{\mathrm{f}}\right)
\end{aligned}
$$

The parameter $b$ in equation (18) can either be treated as an input parameter or, as a first approximation, be estimated as follows.

$$
\begin{aligned}
k_{\mathrm{ff}} & =k_{\mathrm{u}}\left[\frac{\theta_{\mathrm{u}}\left(x_{\mathrm{b}}\right)}{n}\right]^{9} \\
& =k_{\mathrm{u}}\left(\frac{n-I_{\mathrm{b}}}{n}\right)^{9}
\end{aligned}
$$

where $\theta_{\mathrm{u}}$ is unfrozen volumetric water content. The parameter $b$ can be determined by substituting equation (19) into equation (18).

The permeability of a partially saturated soil in the unfrozen state can be approximated by a given saturated permeability

$$
k=k_{\mathrm{sat}} S_{\mathrm{r}}^{m}=k_{\mathrm{sat}}\left(\frac{n-I}{n}\right)^{m}
$$

where $k_{\text {sat }}$ is the saturated permeability, and $m$ is a soil parameter, and a default value of 9 is used in PCHeave, in accordance with equation (19).

The volumetric ice content $(I)$ in the frozen fringe is the difference between the porosity $(n)$ and the unfrozen volumetric water content $\left(\theta_{\mathrm{u}}\right)$. The unfrozen water content is a function of the temperature or a function of the pressure difference $\left(u_{\mathrm{w}}-u_{\mathrm{i}}\right)$. The function used in PCHeave is

$$
\begin{aligned}
I & =n-\theta_{\mathrm{u}}(T) \\
& =n-\theta_{0} \exp \left(\alpha T^{\beta}\right)
\end{aligned}
$$

where $\theta_{0}$ is the initial volumetric water content, and $\alpha$ and $\beta$ are two constants depending on the specific surface area and pore geometry of the soil. The constant $\beta$ is approximately 2 for most soils of interest. The constant $\alpha$ can be determined by substituting into equation (20) an unfrozen water content at a subfreezing temperature (e.g. $\left.-1 \cdot 0^{\circ} \mathrm{C}\right)$.

With equations (15)-(20), the material parameters used in PCHeave are greatly simplified. The final parameters used in PCHeave are listed in Table 3. The thermal conductivity of soil solids is around $2-3 \mathrm{~W} / \mathrm{m} \mathrm{K}$, and the actual thermal conductivity of a soil is calculated according to equations (15)-(17). This parameter is kept as an input, so that non-soils materials such as insulation, snow and concrete can also be simulated in PCHeave. The only 'unusual' soil parameter is the unfrozen water content at $-1{ }^{\circ} \mathrm{C}$ (as a percentage of the initial water content). This parameter is used to back-calculate the parameter $\alpha$ in equation (20). There are various laboratory methods to measure the unfrozen water content in freezing soils. Alternatively it can be back-calculated from one measured value of frost heave. Some typical values for this parameter are $30-80 \%$ for clay, $10-40 \%$ for silt and $0-20 \%$ for sand.
Table 3. Material parameters for each soil layer used in PCHeave

\begin{tabular}{l|l}
\hline Material parameter & Units \\
\hline Bottom position of the soil layer & $\mathrm{cm}$ \\
Thermal conductivity of soil solids & $\mathrm{W} / \mathrm{m} \mathrm{K}$ \\
Water content by dry weight & $\%$ \\
Dry density & $\mathrm{t} / \mathrm{m}^{3}$ \\
Degree of saturation & $\%$ \\
Saturated permeability & $10^{-6} \mathrm{~m} / \mathrm{s}$ \\
Unfrozen water content at $-1^{\circ} \mathrm{C}$ (in percentage of & $\%$ \\
initial water content) & \\
\hline
\end{tabular}

In addition to the material parameters, boundary conditions, groundwater table, external load and geometric make-up of the soil profile must also be specified, as listed in Table 4. The temperatures at the cold and warm boundaries can be specified stepwise in a number of intervals (Table 5). The overburden pressure is the extra load applied at the cold boundary. Soil self-weight is calculated automatically in PCHeave. The size of the time step can affect the results, but the solution converges as the step size is sufficiently small. As the computation in PCHeave is extremely fast (usually in seconds), an appropriate step size can be found by trial and error.

\section{NOTATION}

$A$ soil parameter (default value of 0.5 used in this paper)

$B$ soil parameter (default value of 1 used in this paper)

$g$ acceleration of gravity

$I$ volumetric ice content

$\bar{I}$ mean ice content in current frozen fringe

$I_{\mathrm{b}} \quad$ current volumetric ice content at $x_{\mathrm{b}}$

$K_{\mathrm{e}} \quad$ Kersten number

$k$ permeability of partially saturated soil in unfrozen state

$k_{\text {sat }} \quad$ saturated permeability

$k_{\mathrm{u}}$ effective permeability of unfrozen soil

$L \quad$ specific latent heat of water

$m$ soil parameter (default value of 9 used in this paper)

$N_{\mathrm{l}}$ number of stress cycles that lead to full liquefaction of the soil

$n$ porosity of soil

$S_{\mathrm{r}}$ degree of saturation

$T$ segregational temperature

$T_{\mathrm{c}}$ temperature at location $x_{\mathrm{c}}$

$T_{\mathrm{f}}$ temperature at location $x_{\mathrm{f}}$

$T_{0} \quad$ freezing point of water

$\Delta t \quad$ small time step

$u$ excess pore pressure

$u_{\mathrm{i}}$ pore ice pressure

Table 4. General input parameters in PCHeave

\begin{tabular}{l|l}
\hline Parameter & Units \\
\hline $\begin{array}{l}\text { Number of material layers } \\
\text { Total depth of the soil profile }\end{array}$ & $\mathrm{cm}$ \\
Number of temperature intervals at the cold boundary & \\
Number of temperature intervals at the warm boundary & \\
Overburden pressure at the ground surface & $\mathrm{kPa}$ \\
Groundwater table from the ground surface & $\mathrm{cm}$ \\
Total time length & $\mathrm{h}$ \\
Time step used in the computation & $\mathrm{s}$ \\
\hline
\end{tabular}

Table 5. Boundary temperature specification in PCHeave

\begin{tabular}{l|l}
\hline For each temperature interval & Units \\
\hline $\begin{array}{l}\text { Ending time of the interval } \\
\text { Temperature in the interval }\end{array}$ & $\mathrm{h}$ \\
& ${ }^{\circ} \mathrm{C}$ \\
\hline
\end{tabular}


$u_{\mathrm{n}}$ neutral stress

$u_{\mathrm{w}}$ pore water pressure

$\Delta u$ pore pressure increment

$V_{\mathrm{i}}$ rate of ice lensing or rate of heave during time step $\Delta t$

$v_{\text {ff }}$ rate of water flow in frozen fringe

$v_{\mathrm{u}}$ rate of water flow in unfrozen soil

$w_{\mathrm{u}}$ unfrozen water content at $-1{ }^{\circ} \mathrm{C}$

$w_{0}$ initial water content

$x_{\mathrm{b}}$ warm surface of the latest ice lens (in Fig. 10)

$x_{\mathrm{c}}$ cold boundary of the soil profile for coarse calculation or location of the cold boundary of the growing ice lens

$x_{\mathrm{f}}$ location of frost front

$x_{\mathrm{gW}}$ location of groundwater table

$x_{\mathrm{W}}$ boundary of soil layer below frost front

$\alpha, \beta$ constants depending on the specific surface area and pore geometry of the soil

$\theta$ soil parameter

$\theta_{\mathrm{u}} \quad$ unfrozen volumetric water content

$\lambda$ thermal conductivity of soil solids

$\lambda_{\text {dry }}$ thermal conductivity of dry soil

$\lambda_{\mathrm{f}}$ effective thermal conductivity of layer above $x_{\mathrm{b}}$

$\lambda_{\mathrm{ff}}$ effective thermal conductivity of current frozen fringe

$\lambda_{\mathrm{u}}$ effective thermal conductivity of unfrozen zone

$\rho_{\mathrm{d}}$ dry density

$\rho_{\mathrm{i}}$ density of ice

$\rho_{\mathrm{w}}$ density of liquid water

$\sigma_{0}^{\prime} \quad$ initial (isotropic) effective stress

$\Delta \sigma_{1} \quad$ major principal stress increment

$\Delta \sigma_{3}$ minor principal stress increment

\section{REFERENCES}

Alobaidi, I. \& Hoare, D. J. (1996). The development of pore water pressure at the subgrade-subbase interface of a highway pavement and its effect on the pumping of fines. Geotext. Geomemb. 14, No. 2, 111-135

Beskow, G. (1935). Soil freezing and frost heaving with special application to roads and railroads, Year book 26, no. 3, series C, no. 375. Stockholm Sweden: Swedish Geological Survey.

Biot, M. A. (1956). Theory of propagation of elastic waves in a fluid-saturated porous solid. 1. Low-frequency range. J. Acoust. Soc. Am. 28, No. 2, 168-78.

Cai, Y. Q., Sun, H. L. \& Xu, C. J. (2008). Response of railway track system on poroelastic halfspace soil medium subjected to a moving train load. Int. J. Soils Struct. 45, No. 18-19, 50155034.

Cheng, G. D. (1983). The mechanism of repeated-segregation of the formation of thick layered ground ice. Cold Regions Sci. Technol. 8, No. 1, 57-66.

China Ministry of Railways (2009). Code for design of high speed railway, TB 10621-2009 and J971-2009. Beijing, China: China Railway Press (in Chinese).

Dafalias, Y. F. (1986). Bounding surface plasticity. I: Mathematical foundation and hypoelasticity. ASCE J. Engng Mech. 112, No. 9, 966-987.

Farouki, O. T. (1986). Thermal properties of soils. Clausthal-Zellerfeld, Germany: Trans Tech Publication.

Hayashi, S. \& Shahu, J. T. (2000). Mud pumping problem in tunnels on erosive soil deposits. Géotechnique 50, No. 4, 393408, http://dx.doi.org/10.1680/geot.2000.50.4.393.

Hendry, M. T., Martin, C. D. \& Barbour, S. L. (2013). The measurement of the cyclic response of railway embankments and underlying soft peat foundations to heavy axle loads. Can. Geotech. J. 50, No. 5, 467-480.

Hillel, D. (1971). Soil and water: Physical principles and processes. New York, NY, USA: Academic Press.

Jin, B., Yue, Z. Q. \& Tham, L. G. (2004). Stress and excess pore pressure induced in saturated poroelastic halfspace by moving line load. Soil Dynam. Earthquake Engng 24, No. 1, 25-33.

Kersten, M. S. (1949). Thermal properties of soils, Engineering Experiment Station Bulletin 28. Minneapolis, MN, USA: University of Minnesota.
Kettil, P., Lenhof, B., Runesson, K. \& Wiberg, N.-E. (2008) Coupled simulation of wave propagation and water flow in soil induced by high-speed trains. Int. J. Numer. Analyt. Methods Geomech. 32, No. 11, 1311-1319.

Kolymbas, D. (1991). An outline of hypoplasticity. Arch. Appl. Mech. 61, No. 3, 143-151.

Konrad, J. M. \& Morgenstern, N. R. (1980). A mechanistic theory of ice lens formation in fine grained foils. Can. Geotech. J. 17, No. 4, 473-486

Konrad, J. M. \& Morgenstern, NR. (1981). Segregational potential of freezing soil. Can. Geotech. J. 18, No. 4, 482-491.

Konrad, J. M., Grenier, S. \& Garnier, P. (2007). Influence of repeated heavy axle loading on peat bearing capacity. Proceedings of the 60th Canadian geotechnical conference, Ottawa, Canada, pp. 1551-1558.

Li, M. X. (2008). Study of heaving mechanism and treatment measures of embankment filling on culver of QinhuangdaoShenyang passenger railway. MSc thesis, Beijing Jiaotong University, China (in Chinese).

Li, S. Y., Lai, Y. M., Zhang, S. J., Yang, Y. G. \& Yu, W. B. (2012). Dynamic responses of Qinghai-Tibet railway embankment subjected to train loading in different seasons. Soil Dynam. Earthquake Engng 32, No. 1, 1-14.

Liu, H., Niu, F. J., Niu, Y. H., Lin, Z. J. \& Lu, J. H. (2011). Study of design of filling material and setting anti-frost layer for highspeed railway roadbed in seasonally frozen regions. Chinese $J$. Rock Mech. Engng 30, No. 12, 2549-2557 (in Chinese).

Liu, H., Niu, F. J., Niu, Y. H., Lin, Z. J., Lu, J. H. \& Luo, J. (2012). Experimental and numerical investigation on temperature characteristics of high-speed railway's embankment in seasonal frozen regions. Cold Regions Sci. Technol. 81, 55-64.

Machii, K. (1978). Mud pumping on tracks: present state and counter measures. Jpn. Railway Engng 17, No. 4, 20-21.

Miller, R. D. (1972). Freezing and heaving of saturated and unsaturated soils. Highway Res. Record 393, 1-11.

Muramoto, K., Sekine, E. \& Nakamura, T. (2006). Roadbed degradation mechanism under ballastless track and its countermeasures. Q. Rep. RTRI 47, No. 4, 222-227.

Nishimura, S., Gens, A., Olivella, S. \& Jardine, R. J. (2009). THMcoupled finite element analysis of frozen soil: formulation and application. Géotechnique 59, No. 3, 159-171, http://dx.doi.org/ 10.1680/geot.2009.59.3.159

O’Neill, K. \& Miller, R. D. (1985). Exploration of a rigid-ice model of frost heave. Water Resour. Res. 21, No. 3, 281-296.

Pastor, M., Zienkiewicz, O. \& Chan, A. (1990). Generalized plasticity and the modelling of soil behaviour. Int. J. Numer. Analyt. Methods Geomech. 14, No. 3, 151-190.

Seed, H. B. \& Lee, K. L. (1966). Liquefaction of saturated soil during cyclic loading. J. Soil Mech. Found. Div., ASCE 6, No. 6, $101-110$.

Selig, E. T. \& Water, J. M. (1994). Track geotechnology and substructure management. London, UK: Thomas Telford.

Sheng, D., Axelsson, K. \& Knutsson, S. (1995a). Frost heave due to ice lens formation in freezing soils: 1 . Theory and verification. Nordic Hydrol. 26, No. 2, 125-146.

Sheng, D., Axelsson, K. \& Knutsson, S. (1995b). Frost heave due to ice lens formation in freezing soils: 2. Field application. Nordic Hydrol. 26, No. 2, 147-168.

Sheng, D., Zhang, S., Yu, Z. W. \& Zhang, J. S. (2013). Assessing frost susceptibility of soils using PCHeave. Cold Regions Sci. Technol. 95, 27-38.

Skempton, A. W. (1954). The pore-pressure coefficient A and B. Géotechnique 4, No. 4, 143-147, http://dx.doi.org/10.1680/ geot.1954.4.4.143.

Wong, R. C. K., Thomson, P. R. \& Choi, E. S. C. (2006). In situ pore pressure response of native peat and soil under train load: a case study. J. Geotech. Geoenviron. Engng 132, No. 10, 1360-1369.

Ye, Y. S., Wang, Z. J., Cheng, A. J. \& Luo, M. Y. (2007). Frost heave classification of railway subgrade filling material and the design of anti-freezing layer. China Railway Sci. 28, No. $1,1-7$. 